\section{Nyttig om å treffe ungdom der de er}

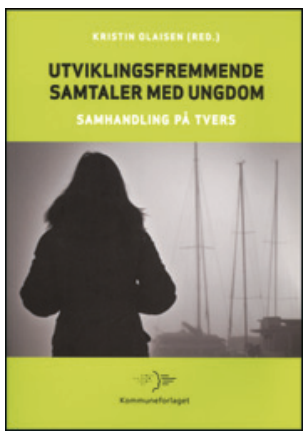

Kristin Olaisen, red

Utviklingsfremmende samtaler med ungdom

Samhandling på tvers. $294 \mathrm{~s}$, tab, ill. Oslo:

Kommuneforlaget, 2012. Pris NOK 200

ISBN 978-82-446-2143-4

«Ungdom i Oslo har sagt sin mening om helsetilbudet i byen og bedre skolehelsetjeneste står høyt på ønskelisten», sto det å lese i Aftenposten i desember 2012.

Utviklingsfremmende samtaler med ungdom er skrevet med akkurat dette for øye. Boken bygger på erfaringene fra et tverrfaglig psykososialt lavterskeltilbud i skolehelsetjenesten i videregående skole i Oslo. Tilbudet startet som et prosjekt på en skole i 2004, og er etter hvert blitt utvidet til flere skoler.

Forskning viser at gruppen 16-20 år med psykiske vansker og psykiske lidelser i liten grad oppsøker det tradisjonelle helsevesenet. Tanken bak prosjektet var å styrke skolehelsetjenesten med ressurser fra spesialisthelsetjenesten for at ungdom skulle få den hjelpen de hadde behov for der de oppholdt seg, nemlig på skolen. Ved å styrke samarbeidet mellom skolehelsetjenesten og spesialisthelsetjenesten ønsket man dessuten å sikre at ungdom med alvorlige psykiske vansker skulle få hjelp raskt og ved behov bli henvist videre.

Boken er oversiktlig, med fire hoveddeler hvor søkelyset er rettet mot rammene for prosjektet, de ulike fagfolkenes erfaringer, ungdommenes erfaringer og relevant kunnskap fra fagområdet. Leservennligheten økes ytterligere ved at boken åpner med en «leserveiledning for dem som vil komme raskt til nettopp sine interesseområder». Målgruppen er bred: studenter og ansatte innenfor helseog sosialfeltet, fagfolk innenfor 1. linje- og spesialisthelsetjenesten, ansatte innenfor skoleverket og politikere og beslutningstakere.

Forebyggende arbeid, tidlig intervensjon og tverrfaglig samarbeid er erklærte mål innenfor det psykiske helsevernfeltet. Målet med samhandlingsreformen er å forebygge mer, behandle tidligere og samhandle bedre. Pasienter og brukere skal få tidlig og god hjelp når de trenger det, og nærmest mulig der de bor.

Tverrfaglig samarbeid er en utfordring, og ulikt faglig ståsted og ulike lovverk kan være til hinder for gode samarbeidsrutiner. Denne boken viser at tverrfaglig og tverretatlig samarbeid er utfordrende, men mulig, nyttig og viktig. En styrke er den praksisnære tilnærmingen. Leserne blir introdusert for ulike problemstillinger og dilemmaer gjennom pasienthistorier som er lette å identifisere seg med ut fra egen klinisk hverdag. Også i kapitlene hvor man presenterer relevant teori og forskning, er den praksisnære tilnærmingen gjennomført. Tverrfagligheten er godt representert, slik at de fleste fagfolk vil finne kapitler spesielt relevante for dem.

Fagfolk innenfor skolehelsetjenesten og beslutningstakere anbefales spesielt å lese boken. Her finnes rikelige muligheter for både å lære og å la seg inspirere.

\section{Ruth-Kari Ramleth}

Nasjonalt senter for selvmordsforskning og -forebygging Oslo

\section{Oppdatert og grundig om ekkokardiografi}

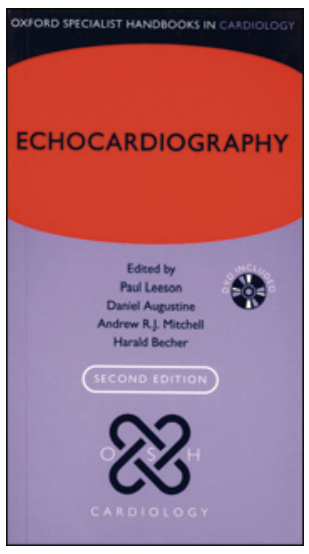

Paul Leeson, Daniel Augustine,

Andrew R.J. Mitchell et al.

Echocardiography

2. utg. 704 S, tab, ill. Oxford: Oxford University

Press, 2012. Pris GBP 45

ISBN 978-0-19-959179-4

Denne boken publiseres i serien Oxford specialist handbooks in cardiology. Med et sideantall på $704 \mathrm{og}$ en tykkelse på $3 \mathrm{~cm}$ kan den få plass i lommen på legefrakken. Men den lille mursteinen vil nok tynge litt under en løpende utrykning når stansalarmen går. Så er den heller ingen minimanual, men en godt gjennomarbeidet og oppdatert lærebok i ekkokardiografiteknikk, med god beskrivelse av ulike modaliteter og tolking av funn.

Forfatterne påpeker selv at de ikke hadde trodd det skulle føles påkrevd å oppdatere så mye så raskt etter at forrige utgave kom i 2007. De har nå lagt vekt på å få med relativt grundige beskrivelser av 3D-ekkokardiografi. Forfatterne beskriver også teknikkene med tøyning (strain), mønstergjenkjenning (speckle tracking), intrakardial ekkokardiografi og kontrastekkokardiografi. Ellers er det, som forventet, innholdsrike og gode kapitler om transtorakal ekkokardiografi, transøsofageal ekkokardiografi og stressekkokardiografi. Akutt ekkokardiografi er viet et eget kapittel, og forfatterne har vektlagt å gi praktiske råd med hensyn til vurdering av væske- og volumstatus hos den dårlige pasienten. Det er flere oversiktlige tabeller med normalverdier og der patologi graderes. Flere av disse tabellene er samlet og gjentatt i et eget siste kapittel slik at det skal være lett å finne raskt tilbake til dem.

Boken inneholder ikke mange referanser, annet enn noen omfattende lærebøker, internasjonale nettsider og retningslinjer, i tillegg til noen få viktige artikler. Som en kuriositet ser jeg at artikkelen til Erlend Aune og medarbeidere (inkludert undertegnede), der vi angir normalverdier for 3D-beregning av venstre ventrikkels volum, er funnet verdig en plass på listen. Overraskende og hyggelig, uten at dette utløser en positiv interessekonflikt. For øvrig er min oppfatning at normalverdiene i noen internasjonale retningslinjer dels selvsagt er basert på studier, men dels litt på konsensusvedtak. Et eksempel er nedre global ejeksjonsfraksjon (EF) på $55 \%$. Vi som er vant til å benytte data fra Vestfold-materialet som normalverdier, finner det også noe strengt å bruke $1,0 \mathrm{~cm}$ som øvre normalverdi for septumtykkelse blant menn, $0,9 \mathrm{~cm}$ blant kvinner.

Det er drøyt 230 fargebilder og 93 fargeillustrasjoner. En CD med 175 filmopptak fra ekkokardiografifunn følger også med. For den som vil gå $i$ dybden på stoffet og få bedre kjennskap til bakgrunn og presisjonsnivå for ulike undersøkelsesteknikker og funn, vil nok mer omfattende lærebøker være nyttige. Men som en pedagogisk vel tilrettelagt, konsis og ryddig beskrivelse av dagens ekkokardiografiteknikk kan den absolutt anbefales.

Olaf Rødevand

Kardiologisk avdeling

Feiringklinikken 